\title{
The brain rotation and brain diffusion strategies of small islanders: considering 'movement' in lieu of 'place'
}

\author{
Godfrey Baldacchino* \\ University of Prince Edward Island, Canada
}

\begin{abstract}
The 'brain drain' phenomenon is typically seen as a zero-sum game, where one party's gain is presumed to be another's drain. This corresponds to deep-seated assumptions about what is 'home' and what is 'away'. This article challenges the view, driven by much 'brain drain' literature, that the dynamic is an epi-phenomenon of the relationship between neo-liberal globalisation and education. Instead, the article invites a consideration of an alternative, cyclical and multiple migration model, both to properly explain at least some of the more contemporary patterns of human traffic across frontiers, as well as to posit a more diffuse, positive-sum model of human capital flows. It does so by focusing on evidence gleaned from a set of territories that would appear, at face value, to be amongst the least likely to come up with dynamic examples of brain diffusion, brain cycles or brain rotation-small islands.
\end{abstract}

\section{Trigger}

In February 2004, I received an email from a sociologist who had been working for some years at the State University of New York at Albany. He informed me that he was leaving Albany for a position at the University of Akureyri in Iceland. I must confess that my first reaction was of utter disbelief: I refused to believe what I was reading. Here was a respected academic, with a decent publications record, about to leave the largest comprehensive university system in the USA educating 410,000 students in 6688 degree and certificate programs on 64 campuses and boasting a 28,000-strong faculty which have won awards including the Nobel Prize, Pulitzer Prize, Fields Medalists, Dirac Medal, National Medal of Science, and Grammy, Emmy and Tony awards. ${ }^{1}$ And for what? He was heading towards the small, peripheral, cold, island

\footnotetext{
* Canada Research Chair in Island Studies, University of Prince Edward Island, 550 University Avenue, Charlottetown PE, Canada C1A 4P3. Email: gbaldacchino@upei.ca
} 
state of Iceland, specifically to the remote northern town of Akureyri and its young university, set up in 1987 and boasting a grand total of 1420 students in $2003 .^{2}$ I asked my colleague to explain his move. He had been offered a full professorship there; but he claimed that 'in the end, it's about family and it is about research interests'. 3 The sociologist had been born and bred in Iceland and he was returning 'home'. It is this discrete event of an immigrant bucking the trend-moving from the core to the periphery - that has triggered off this article.

Iceland-a sovereign island nation, independent since 1944, with a current population of around 280,000 'residents' - in fact enjoys a very high home 'return rate' amongst its young citizens, many of whom spend long periods of time abroad - in the metropolitan heartlands of the USA and Western Europe-for employment or education; even though official statistics do not (and cannot) capture this flux. What are the reasons behind this pattern? Can such a culture of leaving and returning be replicated elsewhere, providing nuggets of public policy to other territories? Or would Icelanders, perhaps the purest and most nationalist people in the world, constitute an idiosyncrasy? What relationship might exist between returned island migrants and specific aspects of island life? What specific development challenges on/for the home island-such as political reform, educational innovation, entrepreneurship support, small business development, management of flagship public/private enterprises and opportunities for direct financial investment-help to lure these mobile citizens back? What are the specific challenges in maintaining a relationship with diaspora communities to which Icelanders might also 'belong'? Can one 'co-habit' home and away? What do we really mean by such terms as: belonging, leaving and returning, residence, home and away? Isn't this a kind of discourse which militates strongly with such established terms as 'brain drain' and 'brain gain'?

\section{Context}

Population, employment and economic capacity continue to concentrate in and around large urban centres. Global competitive trends are leading to the greater concentration of resources associated with the modern knowledge economy (hightech industries, flexible IT-skilled labour pools, research and development institutes, ICT-specialising universities) in large urban centres and metropolitan areas. This trend suggests that new technologies are reinforcing a pattern ushered in by industrialisation: geography (measured as proximity to large centres of population) increasingly matters in the knowledge economy.

The implications of such a dynamic suggest that locations unable to muster a knowledge critical mass will find themselves exporting people, brains, investment and other forms of capital to attractive metropolitan zones or their immediate suburbs. Local employment opportunities will stagnate or fall; actual entrepreneurs will move away; potential ones will look askance. The young and educated people will relocate first, often never to return but to visit relatives and friends on short trips and vacations. Small island locations struggle to survive at best as 'pleasure peripheries' (after Turner \& Ash, 1976). 
On the other hand, bolstered with developments in information and communication technologies (ICTs), the notions of distance, space, place and time need to be radically reviewed and reconfigured. For those who can afford regular physical visit-journeys that crisscross boundaries, along with the modern-day electronic virtual communication paraphernalia of mobile phone, email, Internet chat, web-cam, web-logs, digital photography and/or video streaming, the old dichotomies may be thoroughly erased, and certainly problematised differently (Cohen, 1996). The real 'space-time' costs associated with physical mobility have fallen, making the commitment to tasks underway in a number of diverse physical locations increasingly possible and attractive to local knowledge workers. Thus while geography still matters, it matters in a different way. Mobility is increasingly expected, and the functional-spatial-temporal flexibility of knowledge-capital (as with any other factor of production) is required more than ever. Barriers of ethnicity, nationhood and race are becoming more fluid in drives for specialist recruitment; just as much as barriers of occupational demarcation, trade, employer loyalty or standard working time are thawing away in the face of flexible specialisation, the expansion of the General Agreement on Trade in Services, workforce professionalisation, self-employment, tele-working and traditional trade union demise. The long and short of all this is that being physically available in a certain (read specific) place for a certain (read long and regular) time is increasingly negotiable and contestable, especially by knowledge workers.

Small island territories would represent quintessential peripheral locations. The ingrained openness of small islands serves to orient their island inhabitants towards the metropole, for inspiration, vacation, shopping, education and/or employment. Their literature is dominated by the migration theme (e.g. Markham, 1989; King \& Connell, 1999). Often, emigration is the only medium which permits a viable 'exit' option to the pervasive and stifling totality, monopoly and intimacy of the local sociocultural environment (Baldacchino, 1997). Small island citizens (and not just their elites) are more likely to ape, and be assimilated into, Western culture (Harrigan, 1978; Caldwell et al., 1980; Miles, 1985). They are known to have a higher propensity to migrate to developed countries (Connell \& King, 1999). International migration has in fact long been recognised as heaviest from the world's smallest territories (e.g. Ward, 1967, p. 95). High levels of urbanisation at home act to dislodge residents from outlying villages or islands (in the case of archipelagos) and render them potentially more mobile regionally and internationally (Bertram \& Watters, 1986, pp. 55-57). For various small island households, migration becomes a strategic resource, since offspring sent away can be expected to infuse remittances, in cash or in kind, to the home economy: in some instances (e.g. Samoa and Tonga), these are significant contributions to the gross national product (Ahlburg \& Brown, 1998). At any point in time, a significant percentage of an island population may be away at its respective metropole(s) (Lowenthal, 1987, pp. 41-43; Baldacchino, 1997, p. 89).

This broad external disposition facilitates emigration, typically (though not exclusively) by the brightest and ablest. The urgency for these persons to leave home, the attractions of being lured and relocating away, are bound to increase with the onset of the knowledge economy, along with the falling costs or obstacles to physical mobility. 


\section{Responses}

The repertoire of local responses to this externally disposed condition are various; but most continue stubbornly to stick to the old space-time paradigms, rather than look at the opportunities presented by the new definitions of geography and mobility which are more promising to small island communities. The traditional barriers of strong family ties, disadvantaging aliens seeking employment, citizenship and linguistic skill requirements - assumed by nationality, or imposed by fiscal sanctions, protectionism or other forms of defensive public policy_seek to brake mobility, rather than to exploit or facilitate it. Small island jurisdictions have deployed their separate political status to influence the migration process, making it easier (e.g. via scholarships ${ }^{4}$ ) or harder (e.g. via offering tax credits to those who stay) for local people to leave; as well as making it easier or more difficult for foreigners to settle (e.g. by limiting the type of local property that would-be foreign immigrants are allowed to purchase). ${ }^{5}$ Many countries have traditionally sought to stem the exit of their brightest and ablest by seeking to dissuade, prevent or penalise them for seeking education and/or employment abroad. A number of South Pacific island states, for example, support the view that emigration constitutes a huge net welfare loss to the home country (De Bres \& Campbell, 1975; Hughes et al., 1986; House, 2001). Developing countries react to the brain drain as a 'threat' that would 'undermine' their own development prospects: witness what a recent Department of International Development (DfID) commissioned project set out to investigate, as well as a Commonwealth Secretariat initiative, both focusing on that largest cohort of professionals in most developing countries - teachers. ${ }^{6}$ A similar brain/skill drain is seen as a likely consequence on the 10 newly acceded member states of the European Union. ${ }^{7}$ Meanwhile, even developed countries are not immune from brain/skill drains in relation to the USA, although $9 / 11$ and its aftermath have sharply moderated the rate of immigrant absorption. ${ }^{8}$ Such a strategy however adopts a macro-perspective which fails to recognise and therefore acts to frustrate this, naturally mobile, segment of the population and to harden the resolve of those who have decided to leave and possibly never to return. If successful, 'brain retention' strategies would also prevent and cheat these same citizens from developing the skills and contacts that simply cannot be learnt or obtained by staying 'at home' and which would eventually benefit not only them but their own country, if properly tapped. Of course, it is a big 'if'.

In contrast, other countries actively encourage and sometimes co-finance their talented youth and experienced, mid-career professionals to seek education and/or employment opportunities overseas. This strategy risks a larger loss of critical human capital, but the benefits and synergies associated with those who do return to their native land, often after a deliberate, difficult and conscious decision, are much larger. ${ }^{9}$ The fostering of a 'transnational corporation of kin' amongst South Pacific islanders (Marcus, 1981) facilitates a cyclical migration model where mobility is a deliberate household/kinship group strategy: those who are 'groomed' to leave are expected to return after a sojourn abroad and then, in turn, to help support new immigrants (e.g. Bertram \& Watters, 1985; James, 1991). In the Caribbean, in spite 
of the fractured political map, islands have been recognised as non self-contained units and that there is much rotational migration in the region, ${ }^{10}$ and not merely a steady, net transfer from the island periphery to the metropolitan heartlands of, say, London, Sydney and Miami. The specific cultural and economic circumstances of an island home (including strong family ties, durable friendship networks, the opportunity of faster social mobility and the thought of making a bigger difference in one's small country) may entice some of its mobile citizens to return after a spell abroad, bringing back along with them both experiential and informational knowledge, including potential business contacts (e.g. The Economist, 2003). One's diaspora abroad can serve as a target for lobbying specific investment, culture-friendly tourism and for locating qualified/experienced personnel for demanding and specialised positions. ${ }^{11}$ This is, of course, not a strategy restricted to small islands. ${ }^{12}$

The life-histories of small islanders, where meticulously documented, reveal a complex juggling of the pros and cons of home and away. Thus, both Isaac Caines, from the Caribbean island of St Kitts (profiled in Richardson, 1983, pp. 54-55), and Kawagl, from the Melanesian South Pacific (profiled in Brookfield, 1972, pp. 167-168), demonstrate an uncanny skill in the economies and temporalities of scope (as against scale), which include entrepreneurship, flexible specialisation... and stints abroad. They constitute early examples of what today are called 'transnationals', a specific pattern of de-territorialised and cross-boundary migration that challenges the concept of the temporality and spatiality of 'homeness' (e.g. Vertovec, 2001; Duval, 2004; Hatziprokopiou, 2004). A series of human resource retention, development or reclamation strategies have been and are being developed by enterprising individuals or families in order to nurture and exploit the advantages of a glocal citizenship (after Courchene, 1995); but any such strategies remain often subdued, unarticulated except possibly within households, and typically do not connect with ongoing political processes; education policy, economic policy, labour policy, taxation policy, proprietary rights...all assume that individuals have, or should have, one home, somewhere.

The details surrounding small island migration patterns may have changed since the Caines and Kawagl cases were profiled, but not to the extent that they have eroded the contiguous presence of the values of roots and routes (Clifford, 1997; Jolly, 2001), of a 'rooted mobility' (e.g. Fog Olwig, 1993) or of a 'double identity' (e.g. Bindorffer, 1997). These are the source of 'separation anxiety' ${ }^{13}$ for many islanders: in its disquieting turbulence, the articulation of this dialectic is a consistently powerful feature of island life (Baldacchino, 2004). Indeed, where islander movements are not meticulously documented, especially via longitudinal research methods, the rich, often strategic, manipulation of local/global initiatives is hopelessly lost or, worse, mangled by conventional data-sets (such as census data) that are moulded in a, largely redundant, space-time-rigged universe. Data assume a binary cast, giving the impression that someone must be either a resident or non-resident; must be either here or there; must be either at home or away. 'Belonging' is ascendant; while 'leaving' and 'returning' are not liable to classification.

By practising 'glocalisation' (Robertson, 1995), the international mobile immigrant is neither a total stranger nor an entirely local person in the places that $\mathrm{s} / \mathrm{he}$ haunts, 
visits or inhabits, in both physical and virtual ways. By positing the self 'in-between', $\mathrm{s} /$ he experiences and occupies a third, distinct yet indeterminate space; a cultural hybridity and liminality which confronts the paradigms and fetishism of fixity, duality and identity (Rutherford, 1990, p. 211; Bhabha, 1994; Hoogvelt, 1997, p. 158). Transnationalism may also offer an opportunity to challenge, via the availability of more choices, some functions of territorially specific government (such as by paying most tax where it is charged least and locating investments where the returns are highest), private capitalism (such as in deciding to commit major purchases where they are cheaper) and other conventions (such as by seeking a foreign spouse). It is one's (mobile) body which becomes, as much if not more than physical place, the literal embodiment of 'home'; the ambulatory, a-temporal and a-spatial memory preserve of what might be a planetary (and perhaps soon, a trans-planetary) wide experience (Casey, 2000).

There are indications that 'brain drain/gain' can be reconfigured/ reconceptualised in the context of a multiple, cyclical pattern, even amongst the smallest and most marginal of the world's islands. If so, there is yet hope that globalisation will not necessarily lead to the disproportionate concentration of capital and expertise in mainland, large, urban centres, while the small and insular suffer an ignominious fate as depopulated, resource-starved locations or playgrounds for the rich and famous.

In principle, most theories about the 'brain drain' have considered the advantages and disadvantages of this phenomenon with respect to the sending countries, the receiving destinations and the migrants themselves, often doing so as part of a 'zerosum' game where one country's gain is presumed to be another's loss. Even in luring back talent, the reference is typically to brain drain reversal, not rotation or circulation, as if the only safe thing to do with precious indigenous human capital is to lure it back and then force it to stay, or assume that it would naturally do so. This is naive, may not tally with actual practice and misses the whole point about the need for global citizens to be able to maintain a global outreach and sustain global networks by regularly replenishing them, even if they do so from a 'base' called 'home'. Yet, in using such words like 'base' and 'home', our discourse reveals a stubborn resistance to the old unispatial/unitemporal paradigm.

Perhaps it is time to reform this reductionist model and recognise that a cyclical and multiple migration model may be a powerful tool, both to properly explain at least some of the current movement of human traffic across frontiers and regions, as well as to serve as a positive-sum model of human capital flows. Just like 'tidalectics', the movement of water, backwards and forwards, observers Barbadian poet Edward Kamau Brathwaite (1984).

In fact, a cyclical and multiple — rather than a stark, linear, uni-directional - pattern of 'intellectual capital' flow may prove beneficial to both sending and receiving destinations, as well as to the actual migrants and their families. Information and communication technologies can also make possible knowledge work from/for overseas locations, with a contemporaneity, and not just a succession, of home and away service recipients. If a world dominated by 'the space of flows', as Castells (1999) puts it, is indeed the case, it would be opportune to replace the 'brain drain', 'brain gain' 
or 'brain reversal' terms and their accompanying discourse with more dynamic, more spatially-temporally blurred terms such as 'brain rotation', 'brain cycle', 'brain mobility' or even 'brain diffusion'. ${ }^{14}$

\section{A snap shot}

Connell (1995) presents a case in point. He analyses Samoan migration as depicted mainly through two of the novels, Sons for the return home and Ola, of prominent Samoan writer, Albert Wendt-himself a professional claimed to be part of the "brain drain' syndrome (Wendt, 1973, 1991, respectively). The Samoan migrant that Connell sees in Wendt's novels is one with an evolving identity over time... apparently from being a 'permanent migrant' in New Zealand in the 1960s and 1970s to a contemporary one with an 'ambiguous' identity. Wendt's creative use of language amongst his characters reflects not just the limitations of (colonial) English in accounting for Samoan experiences and expressions; but the mishmash of linguistic codes gleaned from a range of diverse places brought to bear on 'local' situations.

Connell (1995, p. 276) seems convinced that '[d] ichotomies are no longer useful, as the world is revealed to be far more complex involving "movements in specific colonial, neo-colonial and post-colonial circuits, different diasporas, borderlands, exiles, detours and returns"'. Ex-isles are not necessarily exiles (e.g. Bongie, 1998, pp. 18-24).

Wendt himself who, we are reminded, has German ancestry (hence his family name), was born in 1939 in what was then Western Samoa. Still a young boy, he moved with his parents to New Zealand, where he grew up, graduated and started teaching. But this linear migration pattern now becomes 'tidalectic': at age 29, he moved back to Western Samoa; went to Fiji in 1974; returned to Western Samoa; back to Fiji to take up a chair of Pacific Literature at the University of the South Pacific; back to New Zealand to take up a professorship at the University of Auckland; and then on to Hawai'i for yet another academic posting. This shifting, with more likely to come, is interspersed with shorter trips to various locations. Is Samoa 'poorer' for having seen Wendt off?

Between an Icelandic sociologist returning 'home' and the elusive identity/ies of a Samoan writer and his cast, this article has subscribed to the view, echoed amongst others by King et al. (1995, p. x) and Boyd (1989, p. 641), that the focus in migration (and associated brain/human capital transfer) studies needs to shift from place to movement. As with many contemporary knowledge professionals who move around wherever their work may take them (e.g. Ó Riain, 2000, p. 182), mobility is not equivalent to a rootlessness or an uprooting that is invariably construed as a tragic loss. Shuttling between locations and tapping into diasporas provides privileged perspectives to life which call for critical analysis, going beyond the mere issue of remittances. Consequently, there may be benefits for citizens to be outfitted for (rather than precluded or dissuaded from) the opportunity to experience living in other countries.

Such a statement has profound implications. There is already pressure in various (especially developing) jurisdictions to provide courses and qualifications for the purpose of admission to overseas institutions. Metropolitan/urban models of 
schooling may exercise significant influence on domestic policy formulation, elbowing out locally relevant curricula in the process, precisely because they facilitate the upward mobility (read emigration) of the politically powerful local elite (Brock \& Smawfield, 1988, p. 229). The challenge then becomes that of developing glocally relevant school programmes where the periphery 'knows itself' and is valued (Brock, 1988, p. 177), albeit not in a naively narcissistic fashion: the lure of the great beyond is real. In parallel, there is need to devise appropriate policy strategies for attracting mobile citizens back - the skilled and entrepreneurial in particular-not necessarily permanently, but more likely on a selective, temporary or intermittent basis, to their erstwhile 'home': a technique which is claimed to be successfully practised by and from a range of jurisdictions. ${ }^{15}$

\section{Conclusion}

Celebrating the life stories of individuals from small island territories who may have recently migrated in search of education, employment or mere adventure, reveals how such migration patterns are often non-linear and/or cyclical. Similar 'border crossing' narratives could prove timely research pursuits, improving our general understanding of contemporary immigration/emigration patterns and their appropriate, associated policy responses. A dichotomous, 'brain drain/brain gain' discourse would only sit nervously alongside such stories, more at home (pun intended) with the discourse of 'leaving' and 'returning' than that of 'belonging'.

Constitutionally, 'glocal citizenship' may not yet be with us; but the behaviour pattern behind such a status certainly is, with small islanders perhaps leading the way. Already, those who leave and return are making a 'tremendous impact' on their home society. ${ }^{16}$ The situation suggests a dire need to re-examine, and perhaps reproblematise and reconfigure, our understanding of such terms as: place, space, exile, mobility, roots and routes, home and away, brain drain and brain gain.

'Do not confine to the hut, those who inhabit the world' (Dewe Gorodey, New Caledonia, translated by Eric Waddell, in School of Social \& Economic Development, University of the South Pacific, 1993, p. xvi).

\section{Acknowledgements}

I am grateful to Lyla J. Brown, Ronald G. Sultana and the editors and reviewers of Globalisation, Societies and Education for constructive comments on an earlier draft.

\section{Notes}

1. Information from: www.suny.edu/ (accessed 20 March 2005).

2. Information from: www.unak.is/template1.asp?PageID=12 (accessed 20 March 2005).

3. Private email communication, dated 2 June 2004.

4. Smawfield (1993) describes how students from such jurisdictions as pre-1992 Cyprus benefited handsomely from scholarships by virtue of having no local universities. See also Baldacchino (1995). 
5. For example, foreigners in Bermuda are more or less unable to buy land or property, other than houses with an annual rental value in excess of US $\$ 43,800$, equivalent to a sale price of US $\$ 500,000$ approximately. Only 312 houses currently qualify. Visit: www.lowtax.net/lowtax/ $\mathrm{html} /$ bermuda/jbrres.html (accessed 20 March 2005).

6. Teacher brain drain threat, Times Higher Education Supplement, London, 19 March 2004. Available online at: www.nottingham.ac.uk/education/centres/ccer/braindrain.phtml?menu=mobilityc=non (accessed 20 March 2005). The Savannah Accord iterates a concern with the drain of qualified teachers from the Commonwealth Caribbean, partly because of 'recruitment by other countries'. See: www.thecommonwealth.org/shared_asp_files/ uploadedfiles/\%7B3D92204E-19FF-4977-B4B0-C084DFC076A0\%7D_savannah.pdf (accessed 20 March 2005).

7. Brain drain threatens new member states, EU Observer, 26 February 2004. Study report at: www.eurofound.eu.int/newsroom/migration.htm (accessed 20 March 2005).

8. In 2000, the US Congress announced it was raising the annual cap on the number of temporary work visas (H1-B) granted to highly skilled professionals, from 115,000 to 195,000 per year. The events of $9 / 11$, as well as the burst of the dot-com bubble, has led to a reduction of such visas to 65,000 with effect from October 2003. See: www.sfgate.com/cgi-bin/article.cgi?file=/chronicle/archive/2003/10/01/MN55780.DTL (accessed 20 March 2005). This has dented the USA's competitive advantage (Florida, 2005).

9. So, for example, in the case of Samoa: 'From a policy point of view, it is in Samoa's best interest and a monitor of the country's economic health that the circulation of its skilled population within the Pacific and beyond continues to takes place. This circulation will also mean continuity of "aiga" [extended family] identity' (Liki, 2001, p. 15).

10. Evidenced from the work of such anthropologists as Philpott (1973) on Montserrat; Frucht (1968) and Olwig (1993) on Nevis; and Foner (1979) on Jamaica.

11. This is a strategy being used by other, larger countries who have historically been human capital exporters. The EU MEDA-funded ANIMA Regional Program in the Mediterranean is devising a marketing strategy to lure entrepreneurs from the diaspora 'back home'.

12. In 2000, the British government and the Wolfson Foundation launched a $£ 20$ million scheme which sought to attract the return of Britain's leading expatriate scientists (Cervantes \& Guellec, 2002).

13. This is a term coined by David Weale, historian and folklorist from Prince Edward Island, Canada.

14. I owe the inspiration to this term to Lyla J. Brown (private email communication, 8 August 2004). She argues, correctly, that the terms drain/gain and rotation/cycle/mobility suggest a one-place location rather than a multiple-place location. One needs a term that can capture a global/local contemporaneity (the mind [though not the brain] being, somehow, in more than one place at once).

15. Such as assisting the development of 'scientific diasporas'-self-organised communities of expatriate scientists and engineers. See Cordis Focus (European Commission), No. 235, 15 December 2003, p. 21.

16. In the case of another island, Jamaica, Minister Philip Paulwell has claimed that returned migrants leave a 'tremendous impact' on sectors such as banking, business and telecommunications (The Economist, 2003).

\section{Note on contributor}

Godfrey Baldacchino (PhD Warwick) is Canada Research Chair in Island Studies at the University of Prince Edward Island, Canada, and Editor-in-Chief of Island Studies Fournal. 


\section{References}

Ahlburg, A. \& Brown, R. P. C. (1998) Migrants' intentions to return home and capital transfers: a study of Tongans and Western Samoans in Australia, fournal of Development Studies, 35(1), $125-151$.

Baldacchino, G. (1995) Labour formation in small developing states: a conceptual review, Compare, 25(3), 263-278.

Baldacchino, G. (1997) Global tourism and informal labour relations: the small scale syndrome at work (London, Mansell).

Baldacchino, G. (2004) The coming of age of island studies, Tijdschrift voor Economische en Sociale Geografie, 95(3), July, 272-284.

Bertram, G. \& Watters, R. F. (1985) The MIRAB economy in South Pacific microstates, Pacific Viewpoint, 26(3), 497-519.

Bertram, G. \& Watters, R. F. (1986) The MIRAB process: earlier analysis in context, Pacific Viewpoint, 27(1), 47-59.

Bhabha, H. (1994) Between identities (interviewed by P. Thompson), in: R. Benmayor \& A. Skotnes (Eds) Migration and identity, vol. III (New York, Oxford University Press), 183199.

Bindorffer, G. (1997) Double identity: being German and Hungarian at the same time, New Community, 23(3), 399-411.

Bongie, C. (1998) Islands and exiles: the Creole identities of post/colonial literature (Stanford, CA, Stanford University Press).

Boyd, M. (1989) Family and personal networks in international migration: recent developments and new agendas, International Migration Review, 23(3), 638-670.

Brathwaite, E. K. (1984) History of the voice: the development of national language in Anglophone Caribbean poetry (London, New Beacon Press).

Brock, C. (1988) Beyond the fringe? Small states and the provision of education, Comparative Education, 24(2), 167-179.

Brock, C. \& Smawfield, D. (1988) Education and development: the issue of small states, Educational Review, 40(2), 227-239.

Brookfield, H. C. (1972) Colonialism, development and independence: the case of the Melanesian Islands in the South Pacific (Cambridge, Cambridge University Press).

Caldwell, J. C., Harrison, G. E. \& Quiggin, P. (1980) The demography of micro-states, World Development, 8(12), 953-968.

Casey, E. (2000) Remembering: a phenomenological study (Bloomington, IN, Indiana University Press).

Castells, M. (1999) Information age: economy, society and culture (Oxford, Blackwell).

Cervantes, M. \& Guellec, D. (2002) The brain drain: old myth, new realities, OECD Observer, 7 May. Available online at: www.oecdobserver.org/news/fullstory.php/aid/673/ The_brain_drain:_Old_myths,_new_realities.html (accessed 20 March 2005).

Clifford, J. (1997) Routes: travel and translation in the late twentieth century (Cambridge, MA, Harvard University Press).

Cohen, R. (1996) Diasporas and the nation-state: from victims to challengers, International Affairs, 72(3), 507-520.

Connell, J. (1995) In Samoan worlds: culture, migration, identity and Albert Wendt, in: R. King, J. Connell \& P. White (Eds) Writing across worlds: literature and migration (London, Routledge), 263-279.

Connell, J. \& King, R. (1999) Island migration in a changing world, in: R. King \& J. Connell (Eds) Small worlds, global lives: islands and migration (London, Pinter), 1-26.

Courchene, T. J. (1995) Glocalisation: the regional/international interface, Canadian fournal of Regional Science, 18(1), 1-20.

De Bres, J. \& Campbell, R. (1975) Temporary labour migration between Tonga and New Zealand, International Labour Review, 112(6), 455-457. 
Duval, D. T. (2004) Conceptualizing return visits: a transnational perspective, in: T. Coles \& D. Timothy (Eds) Tourism, diasporas and space: travels to promised lands (London, Routledge), 50-61. Economist, The (2003) Jamaica: brain gain,11 October, pp. 38, 42.

Florida, R. (2005) The flight of the creative class: the new global competition for talent (New York, Harper Business).

Fog Olwig, K. (1993) Global culture, island identity: continuity and change in the Afro-Caribbean community of Nevis (Reading, MA, Harwood Academic Publisher).

Foner, N. (1979) Famaica farewell: Famaican migrants in London (London, Routledge and Kegan Paul).

Frucht, R. (1968) Emigration, remittances and social change: aspects of the social field on Nevis, West Indies, Anthropologica, 10(2), 193-208.

Harrigan, N. E. (1978) A theoretical analysis of the concept of microstates: the Raran model, unpublished paper presented at Conference on the Development of Microstates, US Virgin Islands, Caribbean Research Institute, April.

Hatziprokopiou, P. (2004) Balkan immigrants in the Greek city of Thessaloniki, European Urban and Regional Studies, 11(4), 321-338.

Hoogvelt, A. (1997) Globalization and the postcolonial world: the new political economy of development (Baltimore, MD, Johns Hopkins University Press).

House, W. J. (2001) Employment planning: the labour market and the nature and impact of skill losses on the economy of Fiji. ILO Draft Report (Geneva, International Labour Office).

Hughes, H., Ahlburg, D. A. \& Lee, S.-H. (1986) Human resources development in the Pacific Island developing countries, in: Human resources development in Asia and the Pacific: its social dimension (Bangkok, United Nations Educational, Scientific and Cultural Organization), 82-118.

James, K. E. (1991) Migration and remittances: a Tongan village perspective, Pacific Viewpoint, $32(1), 1-23$.

Jolly, M. (2001) On the edge: deserts, oceans, islands, in: V. Diaz \& J. Kehaulani Kauanui (Eds) Native Pacific cultural studies on the edge, special issue, The Contemporary Pacific, Fall, 417-466.

King, R. \& Connell, J. (1999) Small worlds, global lives: small islands and migration (London, Pinter).

King, R., Connell, J. \& White, P. (Eds) (1995) Writing across worlds: literature and migration (London, Routledge).

Liki, A. (2001) Moving and rootedness: the paradox of the brain drain amongst Samoan professionals, Asia-Pacific Population Fournal, 16(1), 1-20.

Lowenthal, D. (1987) Social issues, in: C. G. Clarke \& T. Payne (Eds) Politics, security E development in small states (London, Allen \& Unwin), 26-49.

Marcus, G. E. (1981) Power on the extreme periphery: the perspective of Tongan elites in the modern world system, Pacific Viewpoint, 22(1), 48-64.

Markham, E. A. (Ed.) (1989) Hinterland: Caribbean poetry from the West Indies and Britain (Newcastle upon Tyne, Bloodaxe Books).

Metropolis Project (2001) Brain gain, brain waste, brain drain: using the diversity model to attract and keep talent in Canada. Ottawa, Conversation No.4, January. Available online at: http:// canada.metropolis.net/research-policy/conversation/conversation_4.html (accessed $20 \mathrm{March}$ 2005).

Miles, W. F. S. (1985) Elections \& ethnicity in French Martinique: paradox in paradise (New York, Praeger).

Ó Riain, S. (2000) Net-working for a living: Irish software developers in the global workplace, in: $\mathrm{M}$. Burawoy and collaborators (Eds) Global ethnography: forces, connections and imaginations in a postmodern world (Berkeley, CA, University of California Press), 175-202.

Philpott, S. B. (1973) West Indian migration: the Montserrat case (London, Athlone Press).

Richardson, B. C. (1983) Caribbean migrants: environment and human survival on St Kitts and Nevis (Knoxville, TN, University of Tennessee Press).

Roberston, R. (1995) Glocalization: time-space and homogeneity-heterogeneity, in: M. Featherstone, S. Lash \& R. Robertson (Eds) Global modernities (London, Sage), 25-44. 
Rutherford, J. (1990) The third space: interview with Homi Bhabha, in: Identity, Community, Culture, Difference (London, Lawrence and Wishart), 207-221.

School of Social \& Economic Development, University of the South Pacific (1993) A new Oceania: rediscovering our sea of islands (Fiji, SSED).

Smawfield, D. (1993) Notions of smallness: what are they and what are their implications?, in: K. M. Lillis (Ed.) Policy, planning and management of education in small states (Paris, United Nations Educational, Scientific and Cultural Organization, International Institute for Educational Planning), 25-47.

Turner, L. \& Ash, J. (1976) The golden hordes: international tourism and the pleasure periphery (New York, St Martin's Press).

Vertovec, S. (2001) Transnationalism and identity, Fournal of Ethnic and Migration Studies, 27(4), 573-582.

Ward, R. G. (1967) The consequences of smallness in Polynesia, in: B. Benedict (Ed.) Problems of smaller territories (London, Athlone Press for the Institute of Commonwealth Studies), 81-96.

Wendt, A. (1973) Sons for the return home (London, Longman Paul).

Wendt, A. (1991) Ola (London, Penguin).

Wood, D. P. J. (1967) The smaller territories: some political considerations, in: B. Benedict (Ed.) Problems of smaller territories (London, Athlone Press for the Institute of Commonwealth Studies), 23-34. 